\title{
IMPROVING THE PERFORMANCE OF THE CONCRETE MEMBERS USING NATURAL FIBERS
}

\author{
Karunanidhi. S \\ Asst Professor, Civil Engineering Dept, \\ Wollega University, Post Box No: 395, \\ Nekemte, Ethiopia.
}

\begin{abstract}
-
The indiscriminate infrastructural growth is leading to rapid environmental degradation. Steel, cement, synthetic polymers and metal alloys used for construction activities are energy intensive as well as cause environmental pollution during their entire life cycle. In order to quantify the energy and potential on reduction of $\mathrm{CO}^{2}$ emissions by applying best available technologies. Steel, fibre reinforced plastics etc.. is in form of rods/sheets/fibres/ wires are widely used to improve the performance of concrete. The natural resources may lose in coming days due to its extensive use for the production and enhancing the properties of concrete. It is the time to investigate and invent on the development of alternative reinforcing system. Present study attempted to use the natural fibres which are possible alternative for the existing artificial fibres to enhance the concrete properties. The experiment has been conducted with bamboo fibres as a strengthening material in concrete. In general the strength of bamboo is as high as mild steel while, their density is as low as carbon fibre. The present study the use of the bamboo fibre is proposed to avoid the weak part of bamboo i.e. nodes into the reinforcing medium. The present study showed excellent improvement in the concrete material properties.,
\end{abstract}

Keywords: synthetic polymers, bamboo fibres, carbon fibre, metal alloys.

\section{INTRODUCTION}

Bamboo is a natural perennial grasslike composite and contains lignocellulosic-based natural fibres. Generally it occurs in the natural vegetation of many parts of tropical, subtropical and mild temperature

\author{
Dr. Srinivasan Kumar \\ Asst Professor, Mechanical Engineering \\ Dept, Wollega University, Post Box No: \\ 395, Nekemte, Ethiopia.
}

regions, with about 1250 species identified throughout the world. It reaches its full growth in just a few months and reaches its maximum mechanical resistance in just few years. Therefore Bamboo contains tremendous economic advantage as well. The main problem that it has is less sustainability. But if it is mixed with some durable material like concrete than its durability as well as the strength taking ability will be much higher. This study concentrates on the strength test of composite members made accompanied by bamboo. It determines the compressive strength of beam, prism and cylinders made of bamboo concrete. Different mixing ratios and cross-sectional areas are used for conducting the study.

Unreinforced concrete has a low tensile strength and a low strain capacity at fracture. These shortcomings are traditionally overcome by adding reinforcing bars or prestressing steel. Reinforcing steel is continuous and is specifically located in the structure to optimize performance. Fibers are discontinuous and are generally distributed randomly throughout the concrete matrix. Because of the flexibility in methods of fabrication, fiber reinforced concrete can be an economic and useful construction material.

Globally, the iron and steel sector is the second largest industrial user of energy, consuming 616 Millions of tonnes of oil equivalent and the largest industrial source of Carbon dioxide (CO2) emissions with 2.3 gigatonnes of $\mathrm{CO}^{2}$. There is urgency need for using naturally occurring products as a construction material to decrease the growth of energy consumption and $\mathrm{CO}^{2}$ emissions, replacement of bamboo in place of steel is widely recognized as one of the most important non-timber forest resources because of the high tensile strength and socio-economic 
benefits with bamboo based products. Bamboo has been used as a construction material in certain areas for centuries. As a result, many researchers have been trying to find on nonpolluting and eco-friendly materials. Recently bamboo was consider to make use as a reinforcement material as it behave inelastically even in light loads. This experimental research is focused on the use of bamboo as an additional component in concrete. Bamboo is seismically resisting material and for sustainable environment development without harming our global environment since it absorbs a lot of nitrogen and carbon dioxide from the atmosphere during its growth.

This study is performed mainly for the rural areas, where bamboo is of ample amount, steel is rare, expensive or transportation cost is high. In coastal area the economic condition of people is very poor. In such type of backward area, such study may be essential for their development as well as an assurance for low cost housing. After the study it is seen that samples constructed as aid of bamboo can offer respectable amount of strength that can be safely used for low-cost housing. Conventional reinforced concrete uses steel rebars. However, steel reinforcement is still expensive for many people who want to build houses in large number. To overcome the difficulty, an economical but safe constructional material is needed. Natural fibres can be one possible material, as they are cheap and locally available in many countries. In this work, powdered form of bamboo fibre is used as replacement to steel rebars in Bamboo fibre reinforced concrete (BFRC) specimens.

\section{LITERATURE REVIEW}

Sakaray et al. (2012) investigated the various physical and mechanical properties of bamboo for using as reinforcement in concrete. In this study, authors tested bamboo specimens with a node at middle for the first series and node at $1 / 4$ of length from end for the other series. The tensile, compressive, shear and bond tests were conducted to assess the properties bamboo rods. The bamboo exhibited a uniform identical behaviour like steel, both in tension and compression. The average strength of bamboo is about $125 \mathrm{~N} / \mathrm{mm}^{2}$ is reported from the investigation.Yu et.al. (2011) investigated the concrete specimens with natural fibres. The bamboo is cut in to $10 \mathrm{~mm}$, $15 \mathrm{~mm}$ and $20 \mathrm{~mm}$ length fibres and mixed with concrete. The cubes were cast and tested for assessing the compressive strength. The study is extended with pre-treated and coated bamboo fibres. The author concluded that the rupture strength of the composite is increased by bamboo fibre and the pre-treatment improved the mechanical properties notably.

\section{MIX DESIGN OF BFRC}

Mix design can be defined as the process of selecting suitable ingredients of concrete and determining the relative proportions with the objective of producing concrete of certain minimum strength and durability as economically as possible. As with any other type of concrete, the mix proportions for BFRC depend upon the requirements for a particular job, in terms of strength, workability, and so on. Several procedures for proportioning BFRC mixes are available, which emphasize the workability of the resulting mix. However, there are some considerations that are particular to BFRC. Here Indian Standard method, based on IS 10262-1982 and SP23 is adopted for deriving the mix proportion of M25 Grade concrete

Design procedure-

Characteristic compressive strength at 28 days

$$
=\quad 25 \mathrm{~N} / \mathrm{mm}^{2}
$$

Maximum size of aggregate

$$
=20 \mathrm{~mm}
$$

Degree of Workability

$$
=\quad 0.90
$$

Degree of quality control

$$
\begin{aligned}
\multicolumn{1}{c}{} & \text { Good } \\
\text { Type of exposure } & \\
= & \text { Moderate }
\end{aligned}
$$

Specific gravity of cement

$$
=\quad 3.15
$$

Specific gravity of fine aggregate

$$
\begin{array}{ll}
= & 2.60 \\
\text { Specific } & \text { gravity of coarse aggregate } \\
= & 2.60
\end{array}
$$

Shape of coarse aggregate

$$
=\quad \text { angular }
$$

Grade of cement

$$
=53 \text { grade }
$$

Water absorption of coarse aggregate

$$
=\quad 0.5 \%
$$

Water absorption of fine aggregate

$$
=1 \%
$$


International Journal of Engineering Applied Sciences and Technology, 2019

Vol. 4, Issue 7, ISSN No. 2455-2143, Pages 276-284

Published Online November 2019 in IJEAST (http://www.ijeast.com)

Free moisture of Coarse aggregate

$$
=\quad \mathrm{Nil}
$$

Free moisture of Fine aggregate

$$
=2 \%
$$

Table-1 Sieve analysis of coarse and fine

\begin{tabular}{|c|c|c|}
\hline $\begin{array}{l}\text { Is sieve } \\
\text { size }\end{array}$ & $\begin{array}{c}\text { Fine aggregate } \\
\text { (percent } \\
\text { passing) }\end{array}$ & Remarks \\
\hline $4.75 \mathrm{~mm}$ & 100 & \multirow{6}{*}{$\begin{array}{l}\text { Conforming } \\
\text { to grading } \\
\text { Zone III of } \\
\text { Table } 4 \text { of } \\
\text { IS: } 383-1970\end{array}$} \\
\hline $2.36 \mathrm{~mm}$ & 100 & \\
\hline $1.18 \mathrm{~mm}$ & 93 & \\
\hline $\begin{array}{c}600 \\
\text { micron }\end{array}$ & 60 & \\
\hline $\begin{array}{c}300 \\
\text { micron } \\
\end{array}$ & 12 & \\
\hline $\begin{array}{c}150 \\
\text { micron }\end{array}$ & 2 & \\
\hline
\end{tabular}
aggregate:

Determination of cement content:

$\begin{array}{lll}\text { W/c ratio } & = & 0.5 \\ \text { Water content } & = & 191.61 / \mathrm{m}^{3} \\ \text { Cement } & = & 191.6 / 0.50 \\ & = & 383 \mathrm{~kg} / \mathrm{m}^{3}\end{array}$

Table-2 The mix proportion then becomes:

\begin{tabular}{|c|c|c|c|}
\hline $\begin{array}{c}\text { WAT } \\
\text { ER }\end{array}$ & $\begin{array}{c}\text { CEME } \\
\text { NT }\end{array}$ & $\begin{array}{c}\text { FINE } \\
\text { AGGREG } \\
\text { ATE }\end{array}$ & $\begin{array}{c}\text { COARSE } \\
\text { AGGREG } \\
\text { ATE }\end{array}$ \\
\hline 191.6 & 383 & 546 & 1187 \\
\hline 0.5 & 1 & 1.42 & 3.09 \\
\hline
\end{tabular}

Preparation of bamboo fibres-

The bamboo stem was made to cut into length of $30 \mathrm{~cm}$. Care was taken to neglect the bamboo with nodes as they were found to be weak point in withstanding heavy loads. They were further made into slices of length 8 to 10 $\mathrm{cm}$ and exposed to sunlight for 7days to remove the entire moisture present in it. These fibres were further reduced into size of less than $1 \mathrm{~mm}$ dia and 5 to $6 \mathrm{~cm}$ in length and made to dry in sunlight for 2 days. These fibres are finally preserved and used for the casting process.

\section{EXPERIMENTAL PROGRAM}

Materials used-

Ordinary Portland cement of grade 53, locally available sand, aggregates, potable water and bamboo fibres were used for preparation of plain concrete (PC) and BFRC cubes, cylinders and prisms. The maximum size of aggregate used was $20 \mathrm{~mm}$ (passing through sieve $20 \mathrm{~mm}$ ). . The figure below shows the materials used for casting of conventional concrete specimens . 


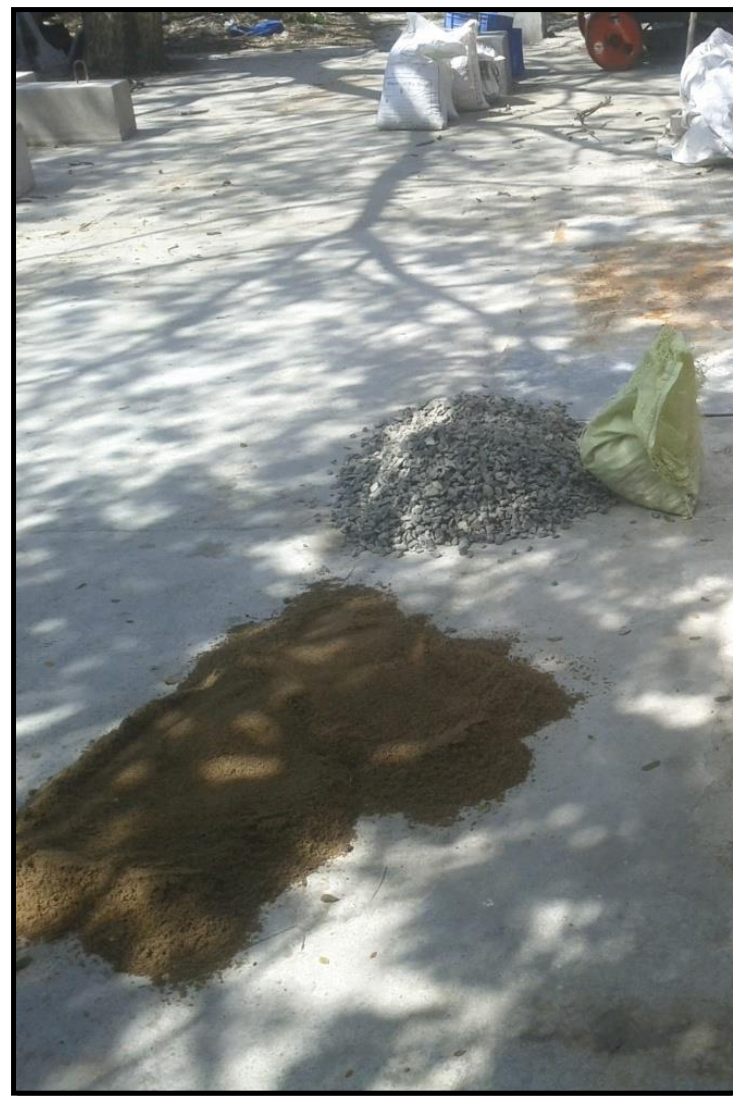

Fig.1.Materials Used For Casting

Casting Of Concrete Cubes, Cylinders And Prisms For Trial Mixes-

Moulds were arranged and oil was applied for easy de-moulding of specimens. Materials were weighed according to the mix ratio. Materials were dropped at the mixer machine in the order of coarse aggregate, fine aggregate and cement. They were dry mixed and then water was poured. The bamboo fibres were added while the mixer rotates. After thorough mixing, the concrete mix was brought near to the vibrating table, where the cube moulds were kept for casting cubes. Concrete was placed in three layers and each layer was vibrated. The casting of cylinders and prisms followed the same pattern as that of cube casting.

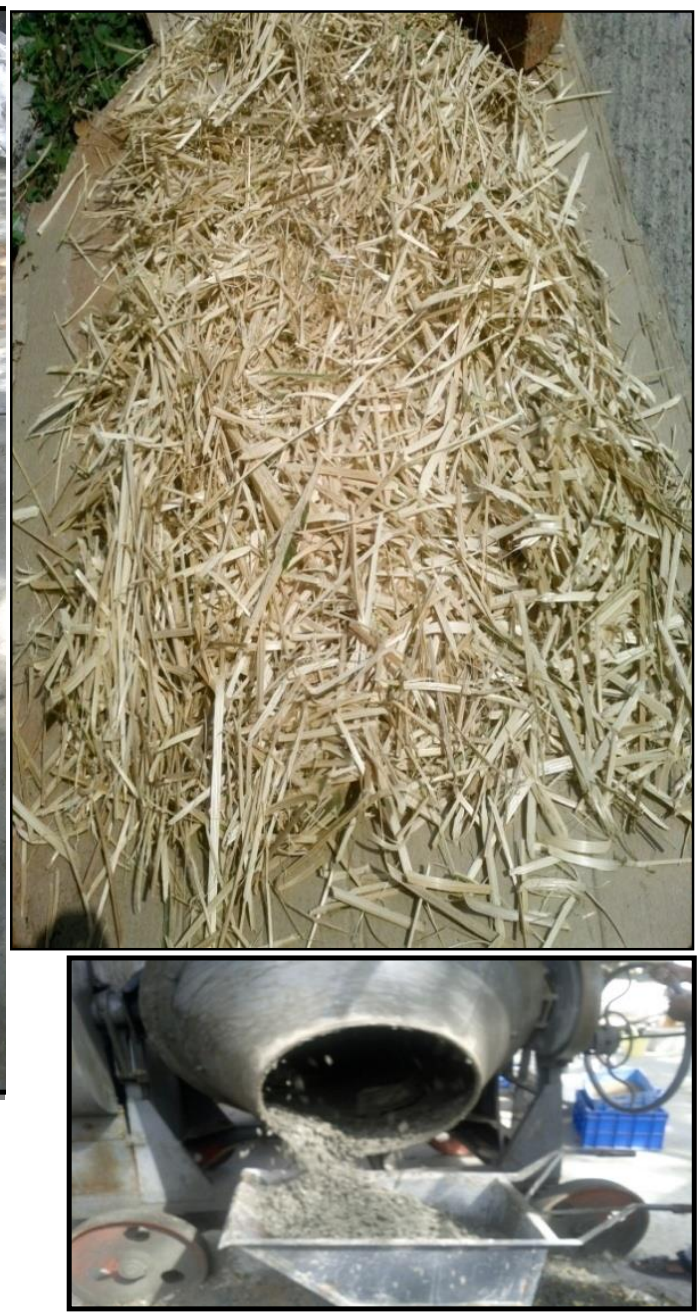

Fig.2 .Mixing Of Concrete

6Nos. of cubes of size $150 \mathrm{~mm} \times 150 \mathrm{~mm}$ $\mathrm{x} 150 \mathrm{~mm}$ for each bamboo fibre mix such as $0 \%, 1 \%, 2 \%, 3 \%, 4 \%, 5 \%$ and $6 \%$ were cast.

Totally 39 Nos. of specimen was casted.

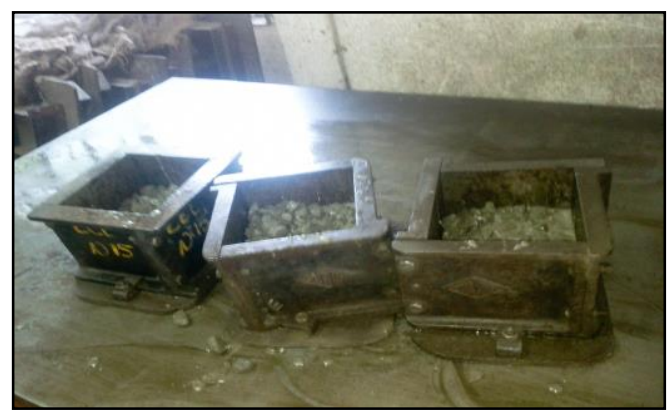

Fig.3.Casting of Cubes 
5Nos. of cylinders of size $150 \mathrm{~mm} \times 300 \mathrm{~mm}$ for each bamboo fibre mix such as $0 \%, 1 \%$, $2 \%, 3 \%, 4 \%, 5 \%$ and $6 \%$ were cast. Totally 35 Nos. of specimen was casted.

4Nos. of Prisms of size $100 \mathrm{~m} \times 100 \mathrm{~m} \times$ $500 \mathrm{~mm}$ for each bamboo fibre mix such as $0 \%$, $1 \%, 2 \%, 3 \%, 4 \%, 5 \%$ and

$6 \%$ were cast. Totally 28 Nos. of specimen was casted.

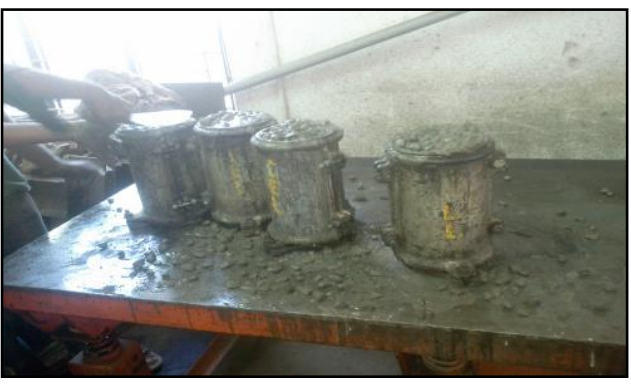

Fig .4.Casting Of Cylinder

Curing of specimens-

Curing is the process by which the specimen is allowed to be placed under water for 7 days to 28 days. This process is mainly done to increase the strength of concrete as the strength cannot be increased by normal exposure under wet atmosphere. So in order to increase the strength this process is carried out.

Testing of cubes and cylinders-

Cube and cylinder were placed one after the other properly in the compression testing machine in such a way that load will be applied uniformly over the cubes and cylinders. Loading was given at the rate of $2.5 \mathrm{kN} / \mathrm{sec}$ and $2 \mathrm{kN} / \mathrm{sec}$ respectively and the readings at the failures were taken. The failure pattern is shown below and the obtained data is tabulated.

Testing of cylinders-

The testing of prisms was conducted in the same testing machine but by means of using flexural setup. The 2point loading has been done by considering the specimen into 3 divisions. The loading was given at the rate of $0.03 \mathrm{kN} / \mathrm{sec}$ and the readings at the failure were taken. The failure pattern is shown below and the obtained data is tabulated.

Split tensile test-
To determine the tensile strength, split tensile test was carried out in the compression testing machine and loading was given at the rate of $1 \mathrm{kN} / \mathrm{sec}$. The failure pattern is noted and the maximum stress value is tabulated.

\section{RESULTS AND DISCUSSIONS}

Cube compressive strength-

The 7 days and 28 days cube compressive strength of plain concrete and fibre reinforced concrete specimens obtained from tests tabulated and bar charts for comparative interpretation are drawn. The figure below depicts the load versus displacement graph of cube compression test.

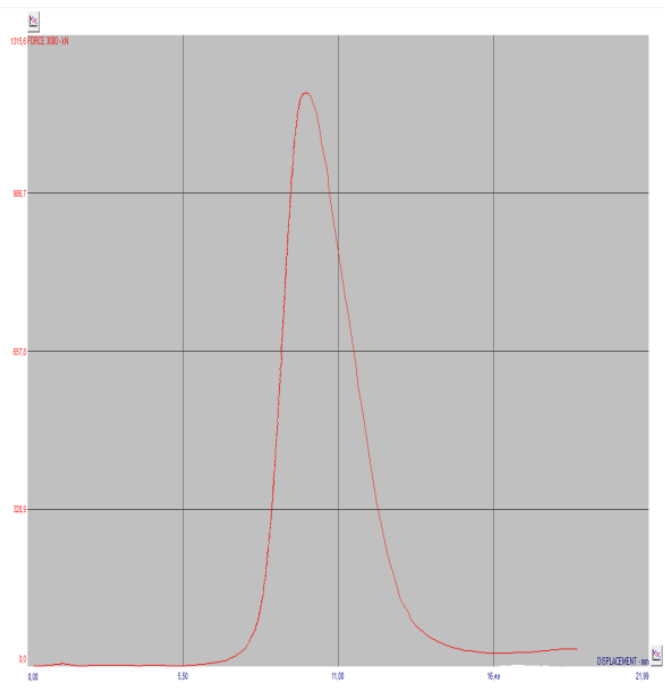

Fig.5. Load-Displacement Curve For Cube Compression Test

The table below gives the test results of 7 days and 28 days cube compressive strength for concrete specimens containing various bamboo content.

Table-3 Cube Compressive Strength Test Results 


\begin{tabular}{|c|c|c|}
\hline $\begin{array}{l}\text { Fibre } \\
\text { Content } \\
\text { (In \%) }\end{array}$ & $\begin{array}{l}7 \text { Days Cube } \\
\text { Compressive } \\
\text { Strength } \\
\left(\mathrm{In} \mathrm{N} / \mathrm{mm}^{2}\right)\end{array}$ & $\begin{array}{l}28 \text { Days Cube } \\
\text { Compressive } \\
\text { Strength } \\
\left(\mathrm{In} \mathrm{N} / \mathrm{mm}^{2}\right)\end{array}$ \\
\hline 0 & 39.09 & 47.30 \\
\hline 1 & 38.6 & 52.20 \\
\hline 2 & 33.17 & 47.30 \\
\hline 3 & 38.31 & 41.88 \\
\hline 4 & 38.98 & 46.93 \\
\hline 5 & 37.27 & 43.78 \\
\hline
\end{tabular}

The bar chart below gives the test results of 7 days and 28 days cube compressive strength for concrete specimens containing various bamboo contents.

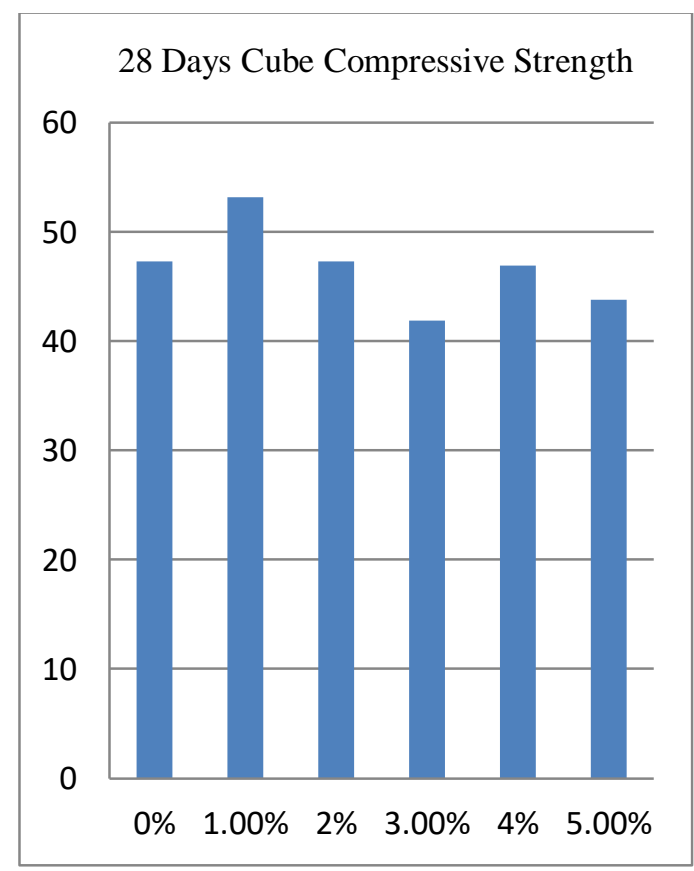

Fig.6.Comparison of Cube Compressive Strength
The cube compressive strength for concrete specimens containing various content of bamboo fibre was obtained and tabulated under Table.3. The comparison of compressive strength of different types of concrete after 7 days and 28 days curing is shown in Fig. 5. It can be seen that addition of fibres upto certain extent increases the compressive strength of concrete and on further addition the strength decreases.

Cylinder compressive strength-

The 7 days and 28 days cylinder compressive strength of plain concrete and fibre reinforced concrete specimens obtained from tests tabulated below and bar charts for comparative interpretation are drawn. The figure below depicts the load versus displacement graph of cylinder compression test.

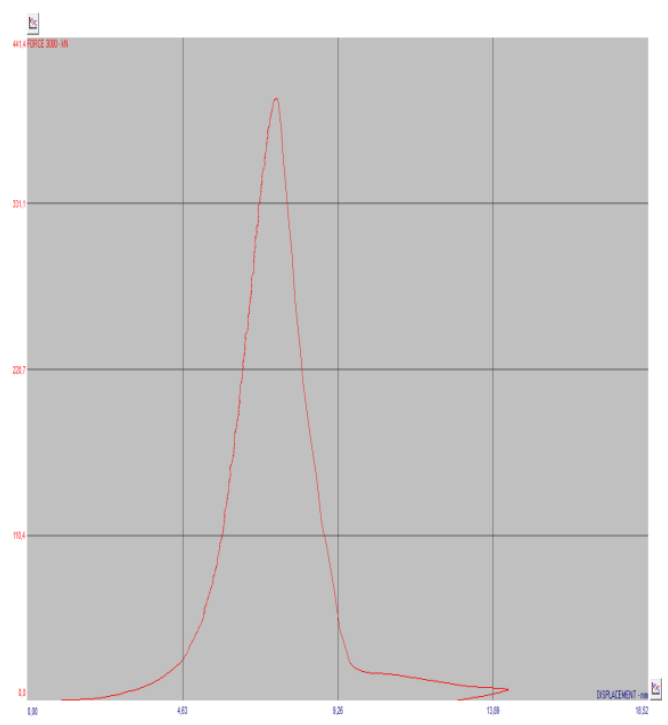

Fig.7. Load-Displacement Curve For Cylinder Compressive Test

The table below gives the test results of 7 days and 28 days cylinder compressive strength for concrete specimens containing various bamboo content. 
The bar chart below gives the test results of 7 days and 28 days cylinder compressive strength for concrete specimens containing various bamboo content.

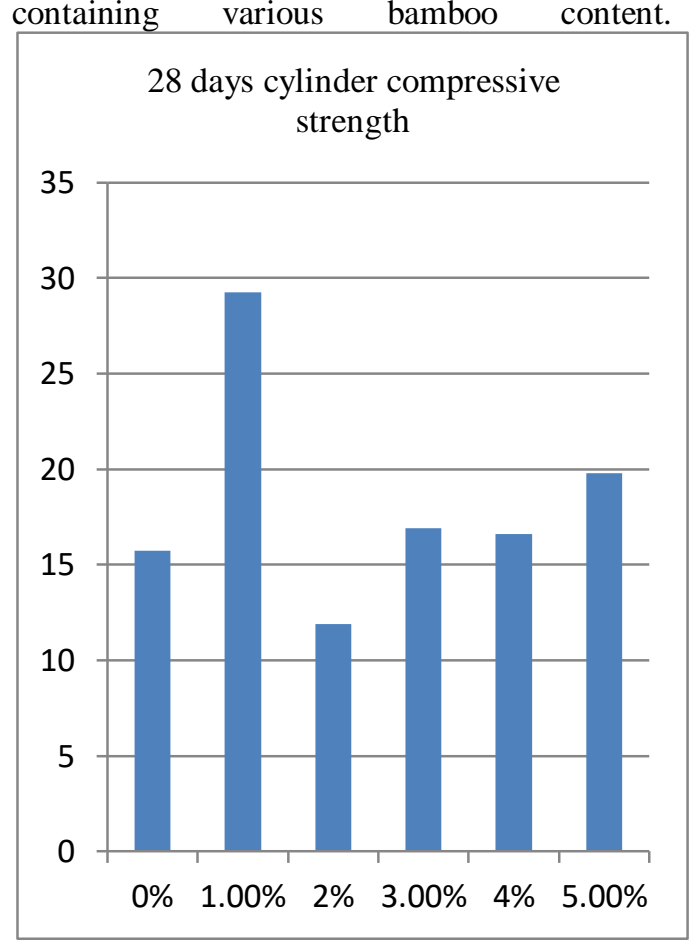

Fig.8.Comparison of Cylinder Compressive Strength

The cylinder compressive strength for different types of concrete specimens was obtained and tabulated under Table 2. The comparison of compressive strength of different types of concrete after 7 days and 28 days curing is tabulated. Similar to cube compressive strength addition of bamboo fibres up to certain extent increases the compressive strength of concrete and on further addition the strength decreases.

Split tensile strength-

The Split tensile strength of plain concrete and fibre reinforced concrete specimens obtained from 28 days tests are tabulated below and bar charts are drawn for comparative interpretation. The figure below depicts the load versus displacement graph of cylinder split tensile test.

The table below gives the test results of 28 days cylinder split tensile strength for concrete specimens containing various bamboo content.

The cylinder split tensile strength of different concrete mixes was obtained from test and tabulated under Table 5.. Shows the
Table-4. Cylinder compressive strength

\begin{tabular}{|c|c|c|}
\hline $\begin{array}{c}\text { Fibre } \\
\text { Content } \\
\text { (In \%) }\end{array}$ & $\begin{array}{l}7 \text { Days Cylinder } \\
\text { Compressive } \\
\text { Strength } \\
(\text { In N/Mm²) }\end{array}$ & $\begin{array}{c}28 \text { Days } \\
\text { Cylinder } \\
\text { Compressiv } \\
\text { e Strength } \\
(\text { In N/Mm²) }\end{array}$ \\
\hline 0 & 16.41 & 15.73 \\
\hline 1 & 12.29 & 29.25 \\
\hline 2 & 11.09 & 11.88 \\
\hline 3 & 14.66 & 16.93 \\
\hline 4 & 20.88 & 16.60 \\
\hline 5 & 19.74 & 19.78 \\
\hline
\end{tabular}

Comparison of tensile strength of different concrete mixes after 28 days curing. It is shown that the average split tensile strength of BFRC specimen containing $2 \%$ of bamboo fibre is higher than the other mix.

Prism flexural strength-

The flexural strength of plain concrete and fibre reinforced concrete specimens obtained from 28 days tests are tabulated below. The testing apparatus set-up and the load versus displacement graph of flexural test is shown below

The table below gives the test results of 28 days prism flexural strength for concrete specimens containing various plastic content.

The prism flexural test of concrete specimens containing different volume of fibres was done at the end of 28 days curing and the results are tabulated. The comparison of flexural strength of different concrete specimens is shown in Fig.5. It is seen that the average flexural strength of 
concrete specimen increased with increase in fibre content.
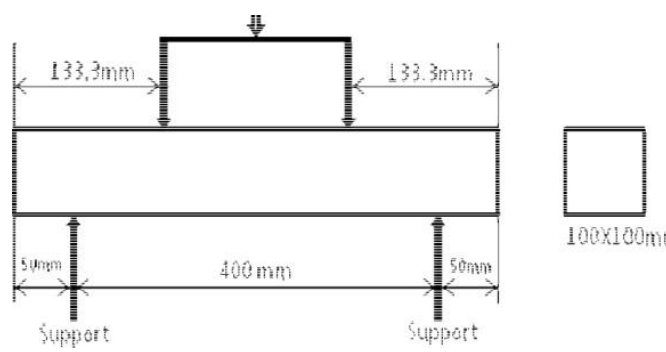

Fig.9. Flexural Test Set-Up

Table-5 Prism Flexural Strength Test Results

\begin{tabular}{|c|c|}
\hline $\begin{array}{c}\text { Fibre } \\
\text { Content } \\
(\text { In \%) }\end{array}$ & $\begin{array}{c}\text { 28 Days Flexural } \\
\text { Strength } \\
(\text { In N/Mm })\end{array}$ \\
\hline 0 & 4.49 \\
\hline 1 & 4.86 \\
\hline 2 & 4.60 \\
\hline 3 & 3.60 \\
\hline 4 & 3.06 \\
\hline 5 & 2.90 \\
\hline
\end{tabular}

Scope for future study-

The study can be extended as follows:

- The preparation of bamboo fibre can be mechanised.

- The usage of bamboo in different forms can be carried out to increase the strength.

- The concrete properties can be enhanced by this type of fibre.

- The addition of bamboo fibre in the percentage with reference to weight can be carried out.

- Bamboo fibre cannot be recycled so steps can be carried out to reuse it.
- The area bears a good potential for further research for more insight in to the suitability of the waste usage in concrete.

\section{CONCLUSION}

Based on the research made with the usage of bamboo fibre in different percentages in concrete, the following conclusion are drawn

- The cube compressive strength increases by nearly $5 \mathrm{~N} / \mathrm{mm}^{2}$ for $1 \%$ addition of bamboo fibres and it is found to decrease by $5 \mathrm{~N} / \mathrm{mm}^{2}$ to10 $\mathrm{N} / \mathrm{mm}^{2}$ when compared to conventional concrete specimen. The increase in compressive strength is found about 10 to 20percent higher compared to the pain concrete.

- The cylinder compressive strength increases by $10 \mathrm{~N} / \mathrm{mm}^{2}$ for $1 \%$ of addition of bamboo fibres whereas it is found to decrease for $2 \%, 3 \%, 4 \%$ and $5 \%$ when compared to conventional concrete specimen. The increase in compressive strength is found about 10 to 20 percent higher compared to the pain concrete.

- The cylinder split tensile strength increases for $1 \%$ addition of bamboo fibres to concrete when compared to conventional concrete specimen thus showing positive trend whereas the remaining addition of fibre shows decreased value. The increase in compressive strength is found as same as cube compressive strength.

- The prism flexural strength increases for $2 \%$ fibres to concrete when compared to conventional concrete specimen.

Thus the usage of $1 \%$ of bamboo fibre increases with various concrete specimens, this would help in increasing the strength of concrete and the availability of bamboo is in large quantity which can now be used in this type of concrete and the waste can be eradicated to maximum level.

\section{REFERENCES}

1. Harish Sakaray,N.V. Vamsi Krishna Togati et al.(2012), “ Investigation on properties of bamboo as reinforcing material concrete", International Journal of Engineering research and Applicaations, Vol 2, Issue-1, Jan-Feb 2012,pp.077-083. 
2. Lima .H.C.et al.(2008), “ Durability analysis of bamboo as concrete reinforcement", International Journal of materials and structures, Vol 41, Issue 5,Jan 2008, pp 981-989.

3. Liu Yu, Zjou Aiguo et al.(2011)," Study on the Mechanical Properties of the Bamboo Fibre Reinforced Cement Composite Materials", International Conference on Agricultural and Natural Resources Engineering, Vol 3-5, 2011.

4. Majid Ali(2012)," Natural Fibres as Construction materials", Journal of Civil Engineering and Consrtruciton Technology, Vol 3, March 2012, pp 80-89.

5. Md.Ahsan Sabbir(2012), " Performance evaluation of Bamboo Twig As A potential reinforcement In Concrete Considering Tensile property", International Journal of Engineering Research and Application,Vol 2, Issue 2 ,may-june 2012, pp 3205-3209.

6. TaraSenetal(2011),"Application of Sisal, Bamboo, Coir and Jute Natural Composites in Structural Upgradation”, International Journal of Innovation, Management and Technology, Vol. 2, No. 3, June 2011.

7. G. Ramakrishna et al(2010)," Evaluation Of Durability Of Natural Fibre Reinforced Cement Mortar Composite- A New Approach", ARPN Journal of Engineering and Applied Sciences,vol 5,No.6, June 10.

8. Kandasamy R., Murugesan R.(2011), "Fibre Reinforced Concrete using Domestic Waste as Fibres", ARPN Journal of Engineering and Applied Sciences, Vol6, Issue-3, March 2011, pp 075-082.

9. Kandasamy R., Murugesan R.(2012), "Fibre Reinforced Self Compacting Concrete using Domestic Waste as Fibres", Journal of Engineering and Applied Sciences, Vol6, Issue-7, 2012, pp 405-410.

10. Venu Malagaveli, Neelakanteswara Rao.(2011), "Strength Characteristics of
Concrete using Solid Waste an Experimental Investigation", International Journal of Earth Sciences and Engineering, Vol4, Issue-6, October 2011, pp 937-940.

11. Handbook On concrete mixes (Based on Indian Standards), SP23.

12. Arivalagan .S (2012)was described Study on the compressive and split tensile strength properties of Basalt Fiber Concrete Members

13. Smriti Raj et al(2014) was described Compressive behaviour of Basalt fiber Reinforced composite

14. RanjitsinhK.Patil et al (2014) was described Comparative Study of Effect of Basalt, Glass, and Steel fiber on compressive and flexural strength of concrete

15. Gordepravinjaysing et al (2014) described performance of basalt fiber in concrete

16. Mr. Gore ke tan R et al (2012)was described The performance of basalt fiber in high strength concrete

17. Mohamadsolikin et al (2013)described Experimental design analysis of ultra fine fly ash, lime water and basalt fiber in mix proportion of high volume fly ash concrete 